\title{
Accounting and valuing the ecosystem services related to water supply in the Central Highlands of Victoria, Australia
}

\author{
Michael Vardon ${ }^{\mathrm{a}, *}$, Heather Keith ${ }^{\mathrm{a}, \mathrm{b}}$, David Lindenmayer ${ }^{\mathrm{a}}$ \\ ${ }^{\text {a }}$ Fenner School of Environment and Society, The Australian National University, Australia \\ ${ }^{\mathrm{b}}$ Griffith Climate Change Response Program, Griffith University, Australia
}

\section{A RTICLEINFO}

\section{Keywords:}

System of Environmental-Economic

Accounting

Water provisioning

Water filtration

Water storage

Exchange value

\begin{abstract}
A B S T R A C T
We examine the theoretical and practical aspects of accounting and valuing the ecosystem services of water provisioning, water filtration and water storage using the System of Environment-Economic Accounting (SEEA) and a case study from Central Highlands of Victoria Australia. We identify: (1) the ecosystem assets providing the ecosystem services, which is both the water body (e.g. lake or artificial reservoir) and surrounding land including the vegetation cover; (2) how these ecosystem services are used as inputs to the production of "Natural Water" as defined in the Central Product Classification used in the System of National Accounts and the SEEA, and; (3) value the ecosystem services using exchange values and the replacement cost method. We propose that for accounting purposes, the generation and use of the ecosystem services of water filtration and water provisioning is simultaneous for the water sources used for supplying water to the economy. The ecosystem service of water provisioning is equal to inflow of runoff and precipitation to reservoirs used by the water industry and recorded at the time of the inflow, not when the water is abstracted and supplied as the product "Natural Water" to households and business.
\end{abstract}

\section{Introduction}

Natural capital accounting is promoted as a way of integrating physical and monetary information on the environment and the economy to provide a more complete and regular source of information to aid decision making in both the public and private sectors (Boyd et al., 2018; Ruijs et al., 2019). The inclusion of ecosystem services in natural capital accounting is a relatively new field of research with much work ongoing (e.g. Bagstad et al., 2013; Barbier, 2014; Eigenraam and Obst 2018; Obst et al., 2015; UN, 2014b; UN, 2017; Vardon et al., 2019; La Notte et al., 2019). While progress has been made, the work has highlighted the difficulties of different professions working together (e.g. accountants, economists, ecologists, hydrologists and government officials), each with their own worldview, research methods and specialist vocabulary. A key aim of this paper is to con- tinue to build understanding between the different professions, which itself has already been a considerable achievement, by presenting a case study of accounting for the ecosystem services used for water supply in the Central Highlands of Victoria, Australia.

Key government decision-making processes revolve around budgeting and economic policy that is underpinned by macro-economic theory linking employment, market demand, saving and investment (e.g., Keynes, 1936; Kuznets, 1949; Clarke et al., 1949). The System of National Accounts (SNA) (UN, 1953) was developed to support macroeconomic decision-making. The SNA covers economic activity - production, consumption and accumulation - in all industries (e.g. agriculture, mining, manufacturing, electricity and water supply, health and education). For more than 50 years, governments and businesses have used information from the SNA in economic analysis and decisionmaking (e.g. Stuvel, 1955; Ruggles and Ruggles, 1999). The theoretical underpinnings of the SNA have not changed substantially since 1953, although the detail has continued to evolve with technological, economic and social change (see EC et al., 2009). The SNA is an information source, providing both a framework for understanding the economy, as well as the data describing the economic system. Accounts consistent with the SNA are produced by virtually all governments of the world. ${ }^{1}$ It has, however, long been recognised that SNA does not adequately account for the inputs from the environment (e.g. Nordhaus and Tobin, 1972) and that economic activity is the key driver of environmental degradation (e.g. Rockström et al., 2009).

Accounting for ecosystem services provides a means to quantify the inputs from the environment to economic activity (UN, 2014b), and

\footnotetext{
* Corresponding author.

E-mail address: michael.vardon@anu.edu.au (M. Vardon).

${ }^{1}$ See the UN National Accounts Statistics: Main Aggregates and Detail Tables. https://unstats.un.org/unsd/nationalaccount/madt.asp.
} 


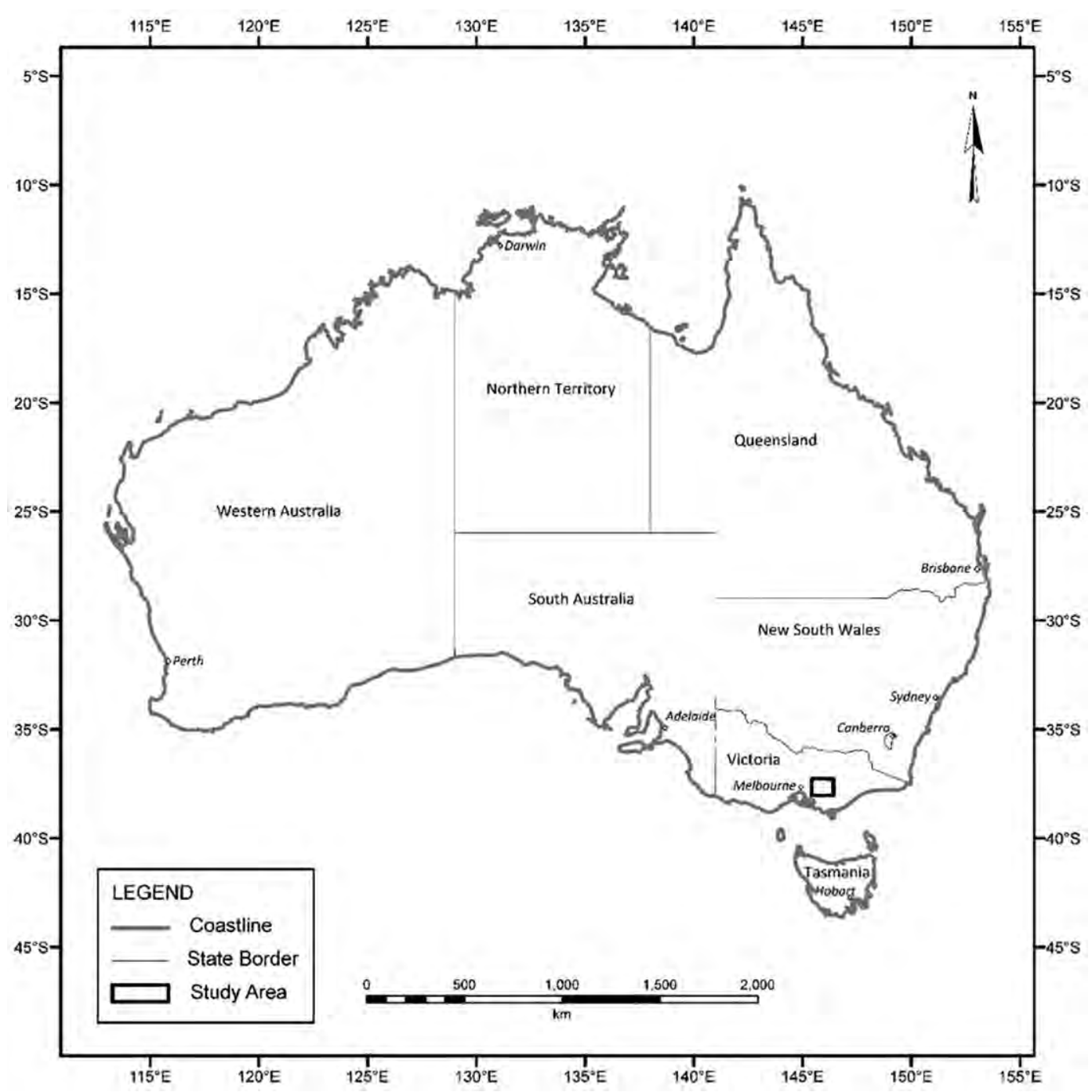

Fig. 1. Map showing location of Victorian Central Highlands, Australia.

human well-being more generally (Boyd and Banzhoff, 2007). This allows more informed decision making as well as providing economic reasons to protect and restore ecosystems. Aligning the concepts of ecosystem services with those of traditional accounting has led to the System of Environment-Economic Accounting Experimental Ecosystem Accounting (SEEA-EEA) (UN, 2014b) and associated technical recommendations to support its implementation (UN, 2017). The recent development of the SEEA-EEA means that there is relatively little experience with its application.

When and where ecosystem services are produced by ecosystems needs to be matched with when and where they are used by economic units (e.g. households and industry). This approach extends the inputs to production considered in the SNA (e.g. Eigenraam and Obst, 2018; La Notte et al., 2019). Here we draw on the SEEA-EEA and other material to test the extended accounting framework and explore options for the treatment and valuation of the ecosystem services related to water supply, using data from the Central Highlands of Victoria in southeastern Australia (Fig. 1).

Ecosystem services related to water supply were chosen as: (1) water is a vital resource in every nation; (2) water is usually managed to ensure consistent supply to people and not as a pure economic good for profit maximisation and; (3) there is growing experience with accounting for water (e.g. ABS, 2017b; BoM, 2016; Edens and Graveland, 2014; Smith et al., 2017; Vardon et al., 2012) and ecosystem services related to water (Egoh et al., 2012; Hackbart et al., 2017; Martinez-
Harms and Balvanera, 2012). In addition, the data for the Central Highlands of Victoria are useful for decision making. This is because there is conflict between the use of forests for water supply, biodiversity protection, carbon storage and timber production in the study area (see Keith et al., 2017).

\subsection{The System of Environmental-Economic accounting (SEEA)}

The System of Environmental-Economic Accounting (SEEA) is an international system for arranging environmental and economic information. It has a series of components (e.g. UN, 2012, UN, 2014a, 2014b) and builds on the SNA (EC, 2009) which, among other things, produces the aggregate GDP (Gross Domestic Product). A key benefit of compiling accounts using SEEA is that different types of environmental information (e.g. land, water, energy, forests, and pollution) is integrated directly with the economic information from the SNA.

The SEEA-EEA (UN, 2014b) and the supporting technical recommendations (UN, 2017) define a range of concepts and articulate a series of accounts for ecosystem assets and ecosystem services. Accounting for water encompasses four parts: (1) the ecosystem service of water provisioning; (2) water as an asset (or stock); (3) ecosystem services related to water provided by a range of ecosystem assets (e.g. water filtration and flood control provided by riparian vegetation); and, (4) water quality as a characteristic of ecosystem condition. This paper focuses mainly on accounting for the first two parts but these also need 
to be seen in context of the last two parts, as we outline later in this paper.

Of particular importance to accounting are the definitions of ecosystem services and benefits, which are:

Final ecosystem services are the ".... contributions to the production of benefits. Final ecosystem services encompass a wide range of services provided to economic units (businesses, governments and households) and may be grouped into provisioning services (i.e. those relating to the supply of food, fibre, fuel and water); regulating services (i.e. those relating to actions of filtration, purification, regulation and maintenance of air, water, soil, habitat and climate) and cultural services (i.e. those relating to the activities of individuals in, or associated with, nature)

Benefits may be SNA benefits - goods or services (products) produced by economic units (e.g. food, water, clothing, shelter, recreation) currently included within the economic production boundary of the SNA; or non-SNA benefits - benefits that accrue to individuals, or society generally, that are not produced by economic units (e.g. clean air). By convention, the measurement scope of nonSNA benefits for ecosystem accounting purposes is limited to the flow of ecosystem services with a direct link to human well-being." (paragraphs 2.5 and 2.6 of UN, 2017)

The key point is that the final ecosystem services contribute to the benefits, which can be products as defined in the SNA. In the case of water, the product "Natural Water" is the benefit produced by the water supplier from the ecosystem services of water filtration and water provisioning, combined with capital inputs (e.g. the dam wall, pipes, pumps), along with energy (e.g. to operate pumps), labour, etc.

When a service is produced and used is an important consideration in accounting. In the SNA and SEEA Central Framework, "Natural Water" is defined as being produced when it leaves a water source, whether the source be a constructed reservoir (i.e. an artificial reservoir) or a natural feature, like a lake, river or subterranean aquifer. However, this view of production was questioned in the process of the development of the SEEA Central Framework, with Nagy et al. (2012) and Obst (2012) recommending that the degree of management of the water resource by water suppliers was such that production should be recognised when the water enters artificial reservoirs. Applying this treatment would then mean that the water within an artificial reservoir would become an inventory within the economy (i.e. owned and managed by an economic unit, e.g. a water supply company). The arguments for this being: (1) the dam wall was constructed specifically to impound water and without the dam wall, water would not be available for supply, and; (2) the water body and surrounding area are usually managed for maintaining a supply of water. The proposal was not accepted and the SEEA Central Framework maintains that economic production occurs when water leaves artificial reservoirs. The development of ecosystem accounting provides a chance to revisit this issue and better align hydrological and accounting concepts for both artificial reservoirs and natural water bodies (e.g. lakes, rivers, groundwater, etc.).

\subsection{Water supply related ecosystem services}

The main ecosystem service examined in this study was water provisioning, but water filtration and water storage are also considered. How water related ecosystem services are defined and treated has been an area of investigation in both the ecosystem services and natural

\footnotetext{
${ }^{2}$ Natural Water is defined in the Central Product Classification (CPC) as: "Potable and non-potable water, suitable for further use, including: treated water (e.g., from desalination plants, water treatment plants); untreated water (e.g., obtained directly from natural sources)" (CPC1800, p. 197, UN 2015).
}

capital accounting communities (Portela et al., 2019). Types of ecosystem services are defined in the Common International Classification of Ecosystem Services (CICES), which is referred to in the SEEA-EEA and was adopted for ecosystem accounting in the European Union (Maes et al., 2013). CICES Version 5.1 is available from the European Environment Agency $^{3}$ and in this water provisioning is defined as: "surface water used for nutrition, materials or energy (items 4.2.1.1 to 4.2.1.3) and; ground water used for nutrition, materials or energy" (items 4.2.2.1 to 4.2.2.3). Other classifications of ecosystem services are provided in various documents such as the Millennium Ecosystem Assessment (MEA, 2005); Final Ecosystem Goods and Services Classification System (FEGS-CS; Landers and Nahlik, 2013), and; National Ecosystem Services Classification System (NESCS; USEPA, 2015). FEGS-CS and NESCS both define services in relation to source of the service, the user of the service, and how the service is used. A review of ecosystem service schemes has recently been published (Finisdore et al., 2019). This review highlights the benefits from using common definitions of ecosystem services, including: facilitating transfer of knowledge between ecosystem service practitioners; integrating data from different studies; increasing credibility of results and; institutionalizing use of ecosystem services in decision making.

Fig. 2 shows three different views of how flows within and between ecosystems and economic units can be represented to highlight the different factors that need to be considered when accounting for the ecosystem services related to water. Water provisioning includes the abstraction of water from ecosystems for all uses (e.g. for drinking water). Where the water is directly abstracted by the beneficiary (e.g. in the case of a person drinking water extracted directly from an artificial reservoir), then they have used the final ecosystem service of water provisioning (Fig. 2a). In the System of National Accounts (EC et al., 2009) and the SEEA Central Framework (UN, 2014a), this would be deemed household own-account production of the product "Natural Water" as defined in the Central Production Classification (CPC) as product CPC 1800 (UN, 2015) and would be recorded as a supply from the water supply industry to households (Fig. 2b). However, if water from the same artificial reservoir is abstracted by the water supply industry for distribution to households for drinking water, then the water supplier has used the final ecosystem service of water provisioning as one of its inputs to the production of "Natural Water" (CPC 1800) which is then supplied to others (e.g. households and industries via pipes). A person drinking water from a tap supplied by an artificial reservoir operated by a water supplier, has used the product "Natural Water", not the ecosystem services of water provisioning (Fig. 2b). In both cases, water filtration also occurs but how this is treated would depend on the number of ecosystems recognised. If, as shown in Fig. $2 a$ and $2 b$, the forest and lake or artificial reservoir are recognised as separate ecosystems, then the water filtration could be treated as an intermediate ecosystem service flow from the forest to the lake or artificial reservoir. However, it could be treated as a final ecosystem service supplied by the forest to the economic entity managing the lake or reservoir. This could then enable the managers of the forest and the lake or reservoir to work together to maximise the benefits of these different ecosystems. In the case where the manager of the lake or reservoir, and the manager of forest are the same, then this could be treated as a type of own-account production and use of an ecosystem service. Regardless of the accounting treatment, water filtration results in higher water quality that could be recorded in water asset accounts that show water condition or the capacity of water assets to supply ecosystem services.

An alternative way to account for these flows would be to show both water provisioning and water filtration as ecosystem services coming from a single spatial unit. Fig. $2 c$ shows a single unit consisting of an

\footnotetext{
${ }^{3}$ See Towards a Common International Classification of Ecosystem Services (CICES) for Integrated Environmental and Economic Accounting https://cices. eu/resources/.
} 


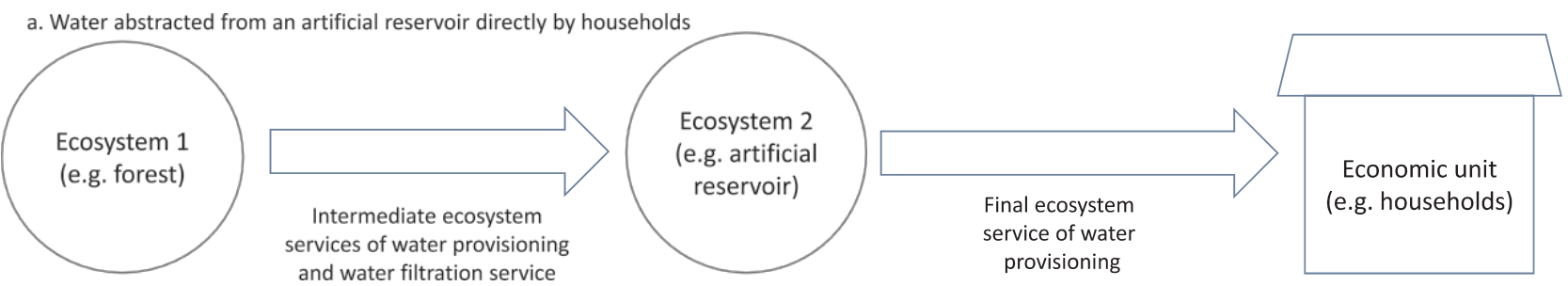

b. Water abstracted from artificial reservoirs by water supply industry, then supplied to households with forests and artificial reservoir shown as two ecosystems

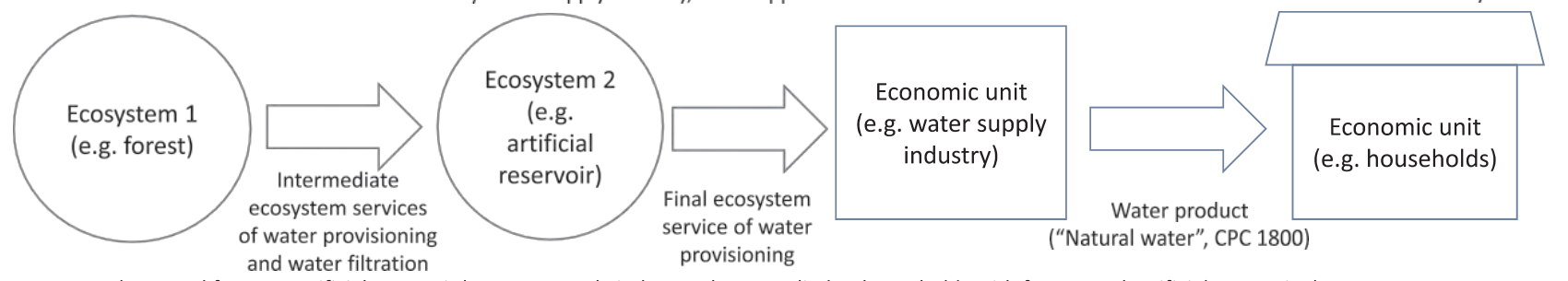

c. Water abstracted from an artificial reservoir by water supply industry, then supplied to households with forests and artificial reservoir shown as one ecosystem

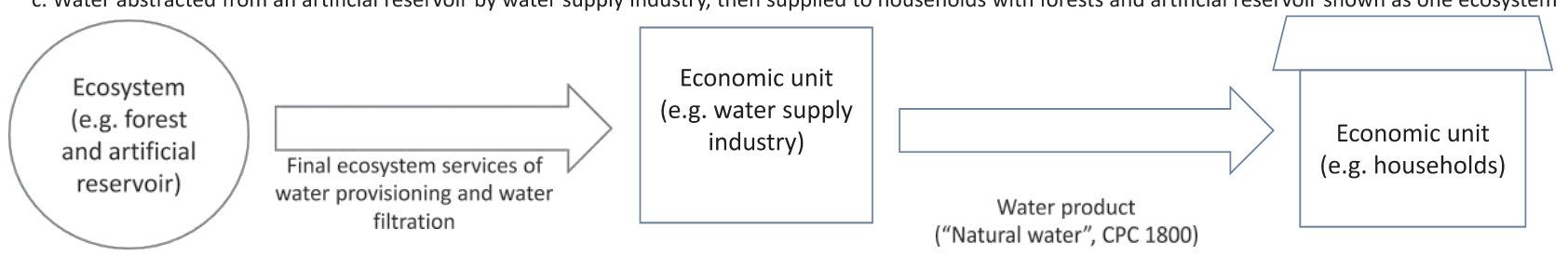

Fig. 2. Alternative views of accounting for flows of the ecosystem services of water provisioning and water filtration.

artificial reservoir surrounded by a forest. Current accounting practices outlined in the SEEA would allow this. If this were the treatment, then the volume of water flowing into the artificial reservoirs would be the volume of the water provisioning service used, and also the volume of water that has benefited from the water filtration service. The water filtration service would usually be measured as the amount of sediment and other pollutants (e.g. pesticides, herbicides, N, P, K, etc.) removed from the water. In some cases, it may be appropriate to use the same metric- volume flowing into the reservoir - as a measure of both the water provisioning and water filtration services, although there would need to be very clear explanation to ensure there was no actual or perceived double counting.

A third possible ecosystem service not defined in CICES Version 5.1 is water storage. This service is provided naturally by, for example, a lake, or perhaps more accurately, the geomorphology that has formed a lake. The service could be measured by the volume of water held in the lake. For artificial reservoirs, a water storage service is also provided but this service results from both the geomorphology and built infrastructure. It is here that the issue of the definition of production in the System of National Accounts (EC, 2009) for the product 'Natural Water' (CPC 1800) is important. As noted earlier, water is not deemed to have been produced until it has left the water source, even if the water source is an artificial reservoir (See Section 1.1). Since "Natural Water" (CPC 1800 ) is not deemed to have been produced until it leaves the reservoir, recording options consistent with System of National Accounts are limited. As ecosystem accounting extends the production boundary of the SNA then there would be an inventory of water held by the water supply industry and this could be the ecosystem service of water storage. The volume held in storage would also be the measure for a natural lake, (i.e. with no artificial infrastructure), which is counterintuitive. The recording and accounting of ecosystem services resulting from ecosystems that are modified or created by people to deliver goods and services to people is an area of research in its infancy (e.g. Barton, 2017) but the accounting treatment for ecosystem services does not depend on the nature of the ecosystem (e.g. natural, human modified or human created).

The management of the areas surrounding watercourses, lakes and artificial reservoirs is important as it affects the level of water provisioning and water filtration services delivered and, in particular, the quality of water and quantity of water. For example, a natural forest (i.e. one where there has been no major human disturbances for many years) will have a different pattern of water flow compared with a cleared area or managed forest (Frame et al., 2009; Langford, 1976; Vertessy et al., 2001). The quality of the water will also be affected. For example, a forest ecosystem is likely to produce higher water quality due to less soil erosion and more limited use of fertilizer, than an agricultural ecosystem. If the water has been contaminated by pollutants (e.g. from chemicals used in agriculture), then these can be absorbed by the vegetation and pollution levels reduced, as was shown in the famous example of the Catskills, New York, USA (e.g. Daily, 1999, NRCCGER, 1999). The type and condition of vegetation also affects the infiltration of water into the ground (Dunne et al., 1991).

\section{Study area, data sources and methods}

\subsection{Study area-Central Highlands of Victoria, Australia}

The study area in the Central Highlands of Victoria contains the majority of the water catchments for the ten water storage reservoirs of the Melbourne Water Corporation, which is owned by the Victorian Government, and supplies water to the city of Melbourne (Melbourne Water, 2015), supporting five million people (ABS, 2018). Melbourne Water manages the storage and supply of water to retail water authorities in Melbourne: City West Water, South East Water and Yarra Valley Water. Water use from these retailers includes residential, commercial and non-revenue use (e.g. water used for firefighting or lost in distribution through leaky pipes).

The water supply catchments cover an area of 157,000 ha in the Yarra Ranges region, with 115,149 ha within the study area (Keith et al., 2017). Some of this area is protected in National Parks and 8932 ha is dedicated specifically to water supply. The total water storage of the ten reservoirs operated by Melbourne Water is $1812 \mathrm{GL}$. Five of these reservoirs are located within the study area. The other reservoirs are further downstream and fed by the same catchments. The 


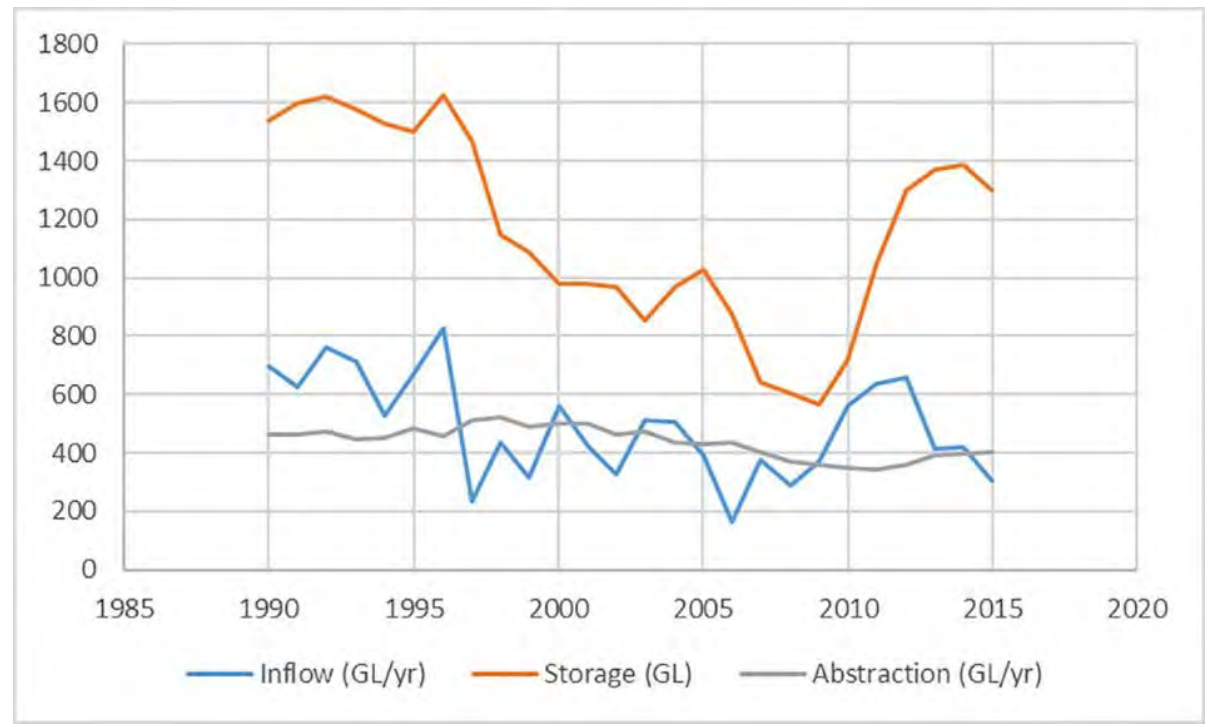

Fig. 3. Time series of water storage inflow (runoff + rainfall directly on reservoir = water provisioning service), and abstraction (=supply of "Natural Water") for the Melbourne Water reservoirs and catchments.

Table 1

Water provisioning service $\left(\mathrm{ML} \mathrm{yr}^{-1}\right)$ classified by land cover over the Central Highlands study area $(735,655$ ha), using an average annual total for each 5-year period.

\begin{tabular}{|c|c|c|c|c|c|c|}
\hline Land cover & 1990 & 1995 & 2000 & 2005 & 2010 & 2015 \\
\hline bare & 33,522 & 38,820 & 28,870 & 21,435 & 13,019 & 42,066 \\
\hline swamp & 61 & 59 & 48 & 47 & 38 & 61 \\
\hline built-up area & 40,237 & 47,497 & 36,572 & 25,923 & 14,052 & 52,559 \\
\hline crop & 1964 & 1945 & 1497 & 1142 & 510 & 2321 \\
\hline crop/pasture/grassland & 19,729 & 23,408 & 17,973 & 12,635 & 6,822 & 25,711 \\
\hline pasture/grassland & 81,576 & 88,391 & 67,224 & 48,903 & 24,376 & 97,546 \\
\hline horticulture & 8,755 & 10,289 & 7,946 & 5,506 & 2,752 & 11,271 \\
\hline pine plantation & 30,794 & 34,382 & 25,282 & 18,987 & 11,129 & 37,258 \\
\hline eucalypt plantation & 61,455 & 72,314 & 54,654 & 38,892 & 21,848 & 79,598 \\
\hline shrub \& heath & 24,470 & 25,108 & 19,669 & 17,505 & 13,077 & 26,668 \\
\hline riparian shrubs & 26,189 & 26,687 & 20,912 & 18,250 & 13,079 & 28,507 \\
\hline woodland & 12,712 & 15,260 & 11,949 & 8,184 & 4,357 & 17,273 \\
\hline montane woodland & 140,066 & 137,990 & 103,426 & 96,688 & 72,876 & 144,984 \\
\hline open mixed forest & 594,173 & 643,267 & 440,591 & 353,956 & 228,955 & 675,159 \\
\hline wet mixed forest & 904,808 & $1,000,743$ & 708,858 & 550,497 & 387,057 & $1,062,748$ \\
\hline alpine ash & 500,190 & 502,009 & 378,299 & 349,860 & 268,102 & 624,202 \\
\hline mountain ash & 750,495 & 807,288 & 606,153 & 511,585 & 377,444 & 969,954 \\
\hline rainforest & 41,651 & 42,162 & 32,632 & 29,381 & 22,159 & 54,648 \\
\hline unknown & 15,125 & 17,707 & 11,746 & 8,856 & 5,803 & 18,282 \\
\hline Total & $3,287,971$ & $3,535,325$ & $2,574,300$ & $2,118,232$ & $1,487,455$ & $3,970,818$ \\
\hline
\end{tabular}

study area contributes to the catchments of the Yarra River and the Tarago/Bunyip Rivers. The Yarra River supplies the majority of water to Melbourne. The Tarago River and reservoir supply water to Westernport Bay and Mornington Peninsula.

We prepared two types of water accounts for the Central Highlands: a physical water asset account and an ecosystem service account for water provisioning. The ecosystem service of water filtration (including dilution, filtration and sequestration of pollutants) was not quantified separately.

\subsection{Data sources}

The water accounts used two main sources of data: (1) Central Highlands study area biophysical data (Keith et al., 2017) and (2) Melbourne Water Corporation water storage and supply data, and financial statements (e.g. Melbourne Water, 2016). All monetary values are shown in Australian Dollars (AUD) in current prices. The physical estimate of the water provisioning service was the runoff or water yield from the study area that flows into the reservoirs operated by
Melbourne Water. Water yield was calculated spatially across the study area and disaggregated for each of the five reservoirs within the region. These data provided information about the spatial distribution of water inflow and the change over time each year in response to climate variability, land cover change, and disturbance history.

A physical water asset account was prepared for the water stored in reservoirs within the study area, which are supplied by runoff from within the study area. The account did not include the stocks of water in rivers, farm dams and groundwater. As well as water additions from rainfall and runoff and reductions from evaporation and abstraction recorded for the artificial reservoirs, there are other potential inflows to the reservoirs from a desalination plant (located at Wonthaggi) and water transfers via a pipeline from outside the study area (via a major artificial reservoir called Lake Eildon) (Viggers et al., 2013).

We did not attempt a monetary valuation of the water assets in this study. Such valuation may be possible based on economic data. For example, resource rent and net present value of expected future income based on receipts, expenses and value of fixed capital could be used (e.g. UN, 2014a), as has been done elsewhere for groundwater assets 
Table 2

Accounts for all Melbourne Water activities (within catchments of 115,149 ha), including volume and value of water supply and water provisioning service.

\begin{tabular}{|c|c|c|c|c|c|c|c|c|c|c|c|c|c|c|c|c|c|}
\hline & 1999-00 & $2000-01$ & 2001-02 & $2002-03$ & 2003-04 & 2004-05 & $2005-06$ & 2006-07 & $2007-08$ & 2008-09 & $2009-10$ & 2010-11 & 2011-12 & 2012-13 & 2013-14 & 2014-15 & 2015-16 \\
\hline \multicolumn{18}{|l|}{ Revenue (\$m*) } \\
\hline Revenue from water supply & 154.9 & 155.8 & 154.4 & 164.5 & 158.8 & 163.7 & 173.8 & 175.4 & 175.5 & 227.3 & 325.5 & 379.7 & 512.3 & 547.6 & 911.2 & 876.2 & 964.2 \\
\hline Other revenue & 322.9 & 305.0 & 325.8 & 346.2 & 345.0 & 364.3 & 418.8 & 412.9 & 424.8 & 504.9 & 532.9 & 617.6 & 727.9 & 710.6 & 805.5 & 873.5 & 889.1 \\
\hline Total revenue & 477.8 & 460.8 & 480.2 & 510.7 & 503.8 & 528 & 592.6 & 588.3 & 600.3 & 732.2 & 858.4 & 997.3 & 1240.2 & 1258.2 & 1716.7 & 1749.7 & 1853.3 \\
\hline \multicolumn{18}{|l|}{ Expenses $\left(\$ \mathrm{~m}^{*}\right)$} \\
\hline Operating \& other expenses & $(98.2)$ & (108.0) & (119.8) & (111.4) & (138.1) & (148.8) & $(167.2)$ & (196.4) & (257.6) & (265.2) & (254.1) & (253.0) & (272.2) & (367.7) & (404.9) & $(408.2)$ & (366.3) \\
\hline Wages, employee benefits & (34.4) & (33.8) & (33.7) & (37.4) & (39.6) & (41.5) & (46.7) & $(50.5)$ & (60.9) & (65.4) & (72.5) & (75.0) & (103.5) & (86.9) & (100.7) & (106.4) & (115.6) \\
\hline Depreciation \& amortisation & (63.2) & (62.9) & (64.8) & (69.3) & (70.3) & (71.2) & $(69.8)$ & (77.4) & (87.5) & (105.8) & (122.0) & (231.9) & (242.6) & (315.9) & (351.6) & (367.5) & (373.8) \\
\hline Financial expenses & (77.8) & (79.8) & (76.1) & (74.2) & (76.3) & (77.9) & (81.2) & (86.6) & (100.8) & (122.0) & (171.3) & (223.3) & (249.2) & (549.3) & $(727.6)$ & $(707.2)$ & (676.7) \\
\hline Total expenses & (273.6) & (284.5) & (294.4) & (292.3) & (324.3) & (339.4) & (364.9) & (410.9) & (506.8) & (558.4) & (619.9) & (783.2) & (867.5) & (1319.8) & (1584.8) & (1589.3) & (1532.4) \\
\hline \multicolumn{18}{|l|}{ Net result $\left(\$ m^{*}\right)$} \\
\hline Net result before tax & 204.2 & 176.3 & 185.8 & 218.4 & 179.5 & 188.6 & 227.7 & 177.4 & 93.5 & 173.8 & 238.5 & 214.1 & 372.7 & (61.6) & 131.9 & 160.4 & 339.2 \\
\hline Tax (expense)/benefit & (7.3) & $(47.2)$ & (55.6) & (68.5) & (56.1) & (62.9) & $(59.0)$ & (43.9) & (25.9) & (45.8) & (52.1) & (56.2) & (102.8) & 21.8 & $(42.0)$ & (44.2) & (185.9) \\
\hline Net result after tax & 196.9 & 129.0 & 130.3 & 150.0 & 123.4 & 125.7 & 168.7 & 133.5 & 67.6 & 128.0 & 186.4 & 157.9 & 269.9 & (39.8) & 89.9 & 116.2 & 153.4 \\
\hline \multicolumn{18}{|l|}{ Estimated IVA ( $\$ \mathrm{~m}^{*}$ ) } \\
\hline For Melbourne Water** & 301.8 & 273.0 & 284.3 & 325.1 & 289.4 & 301.3 & 344.2 & 305.3 & 241.9 & 345.0 & 433.0 & 521.0 & 718.8 & 341.2 & 584.2 & 634.3 & 828.6 \\
\hline For water supply*** & 97.9 & 92.3 & 91.4 & 104.7 & 91.2 & 93.4 & 100.9 & 91.0 & 70.7 & 107.1 & 164.2 & 198.4 & 296.9 & 148.5 & 310.1 & 317.6 & 431.1 \\
\hline \multicolumn{18}{|l|}{ Assets $\left(\$ m^{*}\right)$} \\
\hline Total assets & 2852.1 & 2953.6 & 2994.8 & 3051.4 & 3131.8 & 3263.2 & 3768.7 & 3968.9 & 4435.5 & 5421.1 & 8948.3 & 9754.5 & $10,034.1$ & $14,498.2$ & $14,339.2$ & $14,439.5$ & $14,820.9$ \\
\hline Total liabilities & 1685.1 & 1656.8 & 1666.7 & 1670.0 & 1722.6 & 1769.7 & 1928.6 & 2082.8 & 2448.6 & 3419.3 & 4929.9 & 5379.7 & 5495.1 & $10,117.4$ & 9856.3 & 9714.6 & 9675.2 \\
\hline Net assets & 1167.0 & 1296.8 & 1328.1 & 1381.4 & 1409.2 & 1493.5 & 1804.1 & 1886.1 & 1986.9 & 2001.8 & 4018.4 & 4374.8 & 4539.0 & 4380.6 & 4482.9 & 4724.9 & 5145.7 \\
\hline Number of employees (FTE) & 481 & 488 & 498 & 512 & 501 & 537 & 614 & 645 & 729 & 807 & 828 & 841 & $834^{\#}$ & 832 & 812 & 841 & 885 \\
\hline \multicolumn{18}{|l|}{ Water supply } \\
\hline Volume supplied (ML) & 501,720 & 505,140 & 462,322 & 483,000 & 438,796 & 440,982 & 444,365 & 411,747 & 381,097 & 371,170 & 361,363 & 351,761 & 365,559 & 404,260 & 399,489 & 401,849 & 432,000 \\
\hline Revenue $\left(\$ m^{*}\right)$ & 155 & 155.8 & 154.4 & 164.5 & 158.8 & 163.7 & 173.8 & 175.4 & 175.5 & 227.3 & 325.5 & 379.7 & 512.3 & 547.6 & 911.2 & 876.2 & 964.2 \\
\hline \multicolumn{18}{|l|}{ Water provisioning service } \\
\hline Volume used (ML) & 560,063 & 426,363 & 324,202 & 508,840 & 507,961 & 389,269 & 163,240 & 374,236 & 287,465 & 368,941 & 559,363 & 633,776 & 658,286 & 415,665 & 420,935 & 306,258 & \\
\hline Value used $\left(\$ m^{*}\right)$ & 90.7 & 72.1 & 56.4 & 91.1 & 93.0 & 73.2 & 31.8 & 74.5 & 59.8 & 78.2 & 121.9 & 142.6 & 150.7 & 97.7 & 101.4 & 74.7 & \\
\hline \multicolumn{18}{|l|}{ Water in storage } \\
\hline Volume (ML) & 980,307 & 968,937 & 854,388 & 968,892 & $1,027,661$ & 877,597 & 641,161 & 603,321 & 563,608 & 716,752 & $1,045,479$ & $1,299,733$ & $1,371,971$ & $1,388,928$ & $1,300,186$ & $1,237,716$ & $1,076,432$ \\
\hline
\end{tabular}

*All values shown in Australia dollars (AUD) at current price. ${ }^{* *}$ Estimated IVA for Melbourne Water $=$ wages, employee benefits + depreciation and amortisation + net result before tax

***Estimated IVA for water supply = Estimated IVA for Melbourne Water $\times$ percentage of revenue from water supply. \# Annual Report unclear whether FTE or total number. 
Table 3

Estimates of the value of the water provisioning services in the Melbourne Water catchments $(115,149 \mathrm{ha})$ at replacement cost.

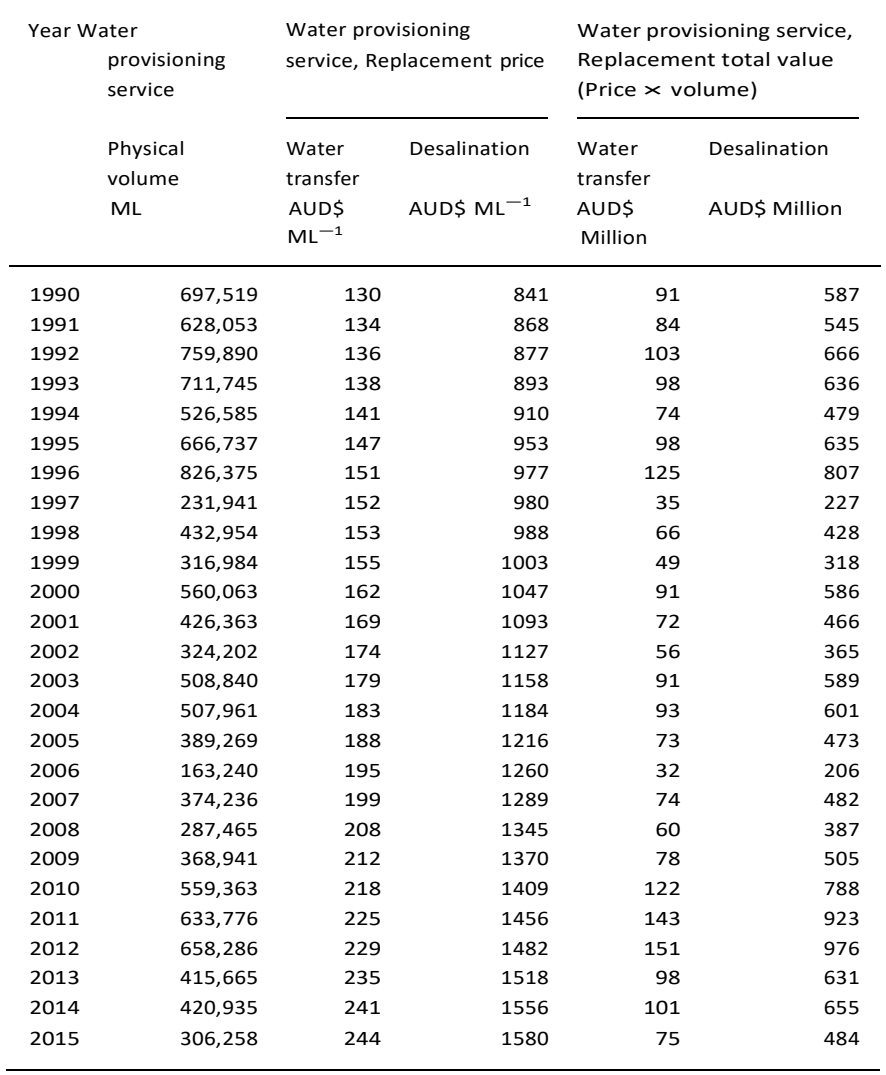

\section{(Fenichel et al., 2016)}

The volume and value of the water supplied by Melbourne Water are given in their annual reports, and includes drinking water, environmental releases, irrigation entitlements, and extra allocations (e.g. Melbourne Water, 2015). The water supplied into the economy is the end result of a combination of fixed capital (e.g. reservoirs, water mains, pumps, etc.), labour and other inputs, as well as ecosystem services. The runoff is equated to the volume of the water provisioning service, but the value of the water supplied is not equal to the value of the water provisioning service. This is because the values of the fixed capital, labour and other inputs need to be deducted. In addition, the price of water in Victoria is regulated (e.g. ESC, 2016) which presents another complication that is discussed later. The water supplied to the economy uses the additional ecosystem service of water filtration but a separate estimate of this service was not made.

The Melbourne Water financial accounts included with their Annual Reports were the source of information on the revenue from water supply as well as production costs. These data were used to generate an estimate of the value added by the company, aligned with the concepts of Industry Gross Value Added in national accounting (EC et al., 2009).

\subsection{Valuation methods}

We considered three methods from the SEEA-EEA (UN, 2014b) for the valuation of the ecosystem service of water provisioning: (1) resource rent; (2) production function, and (3) replacement cost.

The resource rent method was not used owing to the constrained nature of the water market in Victoria, where prices are regulated by the Essential Services Commission (ESC) (ESC, 2016), likely leading to the calculation of negative resource rent. These issues have been noted previously in Australia by Comisari et al. (2011) and in the Netherlands by Edens and Graveland (2014). An additional factor in the rejection of the resource rent method was the lack of data on the value of the water supply infrastructure and the costs associated with water supply in the Annual Reports of Melbourne Water. While the Annual Reports contain some information about these costs, the data are presented as the combined values of water supply and sewerage infrastructure, whereas separate information about these is required for resource rent calculations. Similarly, the information about water supply is included with the sewerage industry in the Australian System of National Accounts (e.g. ABS, 2017a).

Lack of data also was the reason for rejecting the production function approach. In the case of water from the Central Highlands, the water provisioning services are used by Melbourne Water but the revenue received for the supply of water is, as noted above, price constrained. The benefits of the price constraint are to the consumers of the water supplied by Melbourne Water. As such, the production function approach would require detailed information on all of the water consumers in Melbourne and, in particular, the value of the water and all other inputs to the productive activities of business using water (which would effectively be all businesses in Melbourne).

The least cost replacement method was used to value the water provisioning services, broadly following the method of Edens and Graveland (2014). The replacement cost method assumes that: (1) the service, if lost, would be replaced by consumers, and (2) the consumption pattern would be unaffected by any increase in cost. Three options were investigated for the replacement cost of water: (1) transfer of water from other regions; (2) use of desalinated water; and (3) use of recycled water.

\subsubsection{Transfer of water from other regions}

Water can be traded between regions in Victoria, with the price of water allocations varying over time and by location. The price ranged from AUD\$30 to $\$ 100$ per ML between $2010-11$ and 2013-14, (DELWP, 2015). The purchase of water from other regions (e.g. from northern Victoria) and its transport to supply Melbourne is possible, although subject to regulatory approval. Melbourne Water could transport water to its distribution network via an existing pipeline, the $70 \mathrm{~km}$ long Yea-Sugarloaf pipeline, which can move up to $75 \mathrm{GL} \mathrm{yr}^{-1}$. It was completed in 2010 at a cost of AUD\$750 million (Melbourne Water 2010). Assuming a 75-year asset life for the pipeline and a linear depreciation (i.e. AUD\$10 million per annum), the capital cost is AUD $\$ 133 \mathrm{ML}^{-1}$. However, operation of the pipeline is energy-intensive which adds significantly to the cost. Energy is typically the biggest cost in water systems (e.g. Delgado et al., 2015). Energy use by Melbourne Water increased by 222,000 GJ between 2008-09 and 2009-10 due to the operation of the Yea-Sugarloaf pipeline, as well as the energy requirements of another pumping station and a wastewater treatment plant (Melbourne Water 2010, p. 26). Assuming the pipeline used onethird of the additional energy, this is $74,000 \mathrm{GJ}$ to transport $16.7 \mathrm{GL}$ (Melbourne Water 2010 p. 26). In 2009-10, Melbourne Water's total energy use was $1,638,000$ GJ and energy expenditure was AUD\$20.2 million (Melbourne Water 2010 p. 27). This represents an energy cost of AUD\$55 per ML transported. Summing these costs, the total cost of replacing water would be around AUD\$218 per ML in 2009-10 based on the sum of: AUD\$30 per ML for purchase on water allocation (using the lowest value), AUD\$133 per ML for the estimated capital cost of the pipeline, and AUD\$55 for the energy cost.

\subsubsection{Use of desalination}

The cost of desalination was determined from the information available on the Wonthaggi Desalination Plant that was built to supply water to Melbourne in case of the failure of other water sources. The price was AUD\$1.37 per kilolitre ( $\$ 1370$ per ML) in 2009 (Department of Treasury and Finance, 2009), which was based on the assumption of the plant operating at full capacity ( $150 \mathrm{GL}$ per year) for 27.75 years. Construction of the plant cost AUD\$3.5 billion and was built between 2009 and 2012. The net present cost of financing, building and 
Accounting for ecosystem services related to water supply in the Central Highlands of Victoria 2014-15: production consistent with the SNA.

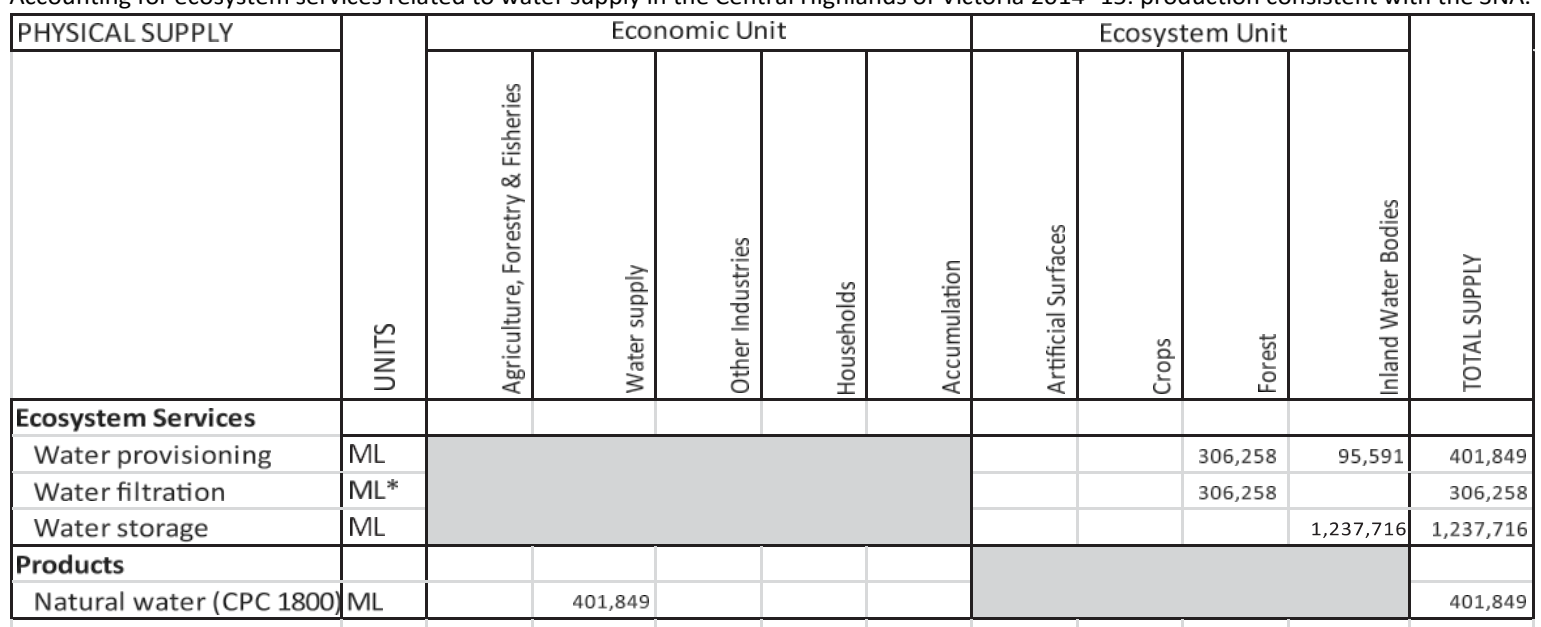

\begin{tabular}{|c|c|c|c|c|c|c|c|c|c|c|c|}
\hline \multirow[t]{2}{*}{ PHYSICAL USE } & \multirow[b]{2}{*}{$\stackrel{\curvearrowleft}{\stackrel{\varrho}{ٍ}}$} & \multicolumn{5}{|c|}{ Economic Unit } & \multicolumn{4}{|c|}{ Ecosystem Unit } & \multirow[b]{2}{*}{$\begin{array}{l}\text { 岕 } \\
\frac{\vec{\Xi}}{5} \\
\stackrel{5}{\circ}\end{array}$} \\
\hline & & 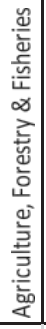 & 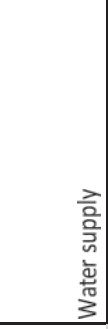 & 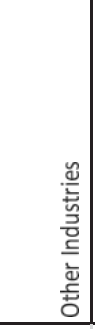 & 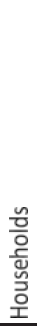 & 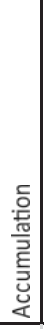 & 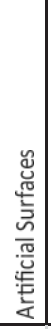 & $\begin{array}{l}\tilde{0} \\
\frac{0}{2} \\
\end{array}$ & 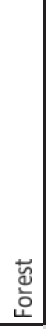 & 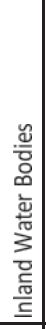 & \\
\hline \multicolumn{12}{|l|}{ Ecosystem Services } \\
\hline Water provisioning & ML & & 401,849 & & & & & & & & 401,849 \\
\hline Water filtration & ML* & & 306,258 & & & & & & & & 306,258 \\
\hline Water storage & $\mathrm{ML}$ & & $1,237,716$ & & & & & & & & $1,237,716$ \\
\hline \multicolumn{12}{|l|}{ Products } \\
\hline Natural water (CPC 1800) & $\mathrm{ML}$ & & & 401,849 & & & & & & & 401,849 \\
\hline
\end{tabular}

*Water filtration service would usually be measured as amount of sediment and other pollutants (e.g. pesticides, herbicides, $\mathrm{N}$, $\mathrm{P}$, $\mathrm{K}$, etc.) removed from the water.

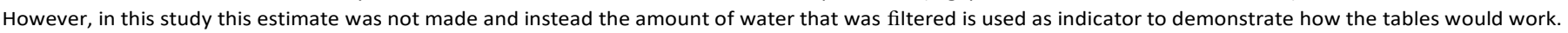

operating the plant over 30 years is AUD\$5.7 billion (assuming water orders of $150 \mathrm{GL} \mathrm{yr}^{-1}$ ). It is unclear if this cost also includes the cost of pipes and pumping to transport the water produced via desalination to the existing distribution network. If they were not included, then this would increase the cost of desalinisation as an alternative source of water. The results, presented and discussed in Section 3, revealed that desalinisation was not the cheapest option and hence was not investigated further.

\subsubsection{Use of recycled water}

The recycling and treatment of wastewater from the sewerage and stormwater systems and its supply to water users already occurs. The volume of treated wastewater available for recycling supplied by Melbourne Water in $2014-15$ was $295 \mathrm{GL} \mathrm{yr}^{-1}$, and this has been increasing steadily from $43.8 \mathrm{GL}$ in 2005-06 (volume excludes environmental flows) (Melbourne Water, 2009). The water supplied cannot be used for drinking and is not yet an equivalent product to most of the water supplied from the catchments by Melbourne Water to households and business. It could, however, be used for some purposes, such as irrigation of sports fields and industrial processing. Unfortunately, the costs associated with production of recycled water are not easy to determine from accounts of Melbourne Water owing to the value of capital assets for water supply and sewerage being presented together and it is not known if the water can be transported via the existing water distribution network. The price for recycled water charged by Melbourne Water provides a guide: in 2006-07 revenue from recycled water was $\$ 2.0$ million for the supply of $61 \mathrm{GL}$ (Melbourne Water, 2009 pp 30-31) or AUD\$33 per ML. Given that recycled water is not an equivalent product and cannot be used as a replacement for all water currently supplied by Melbourne Water this value was not used to estimate the replacement cost for the water provisioning service generated by the catchments in the Central Highlands.

\subsubsection{Adjusting for inflation}

The prices for water transfer and desalination were applied to all other years, adjusted for inflation using the Australian Consumer Price Index Inflation Calculator (ABS, 2016). For these calculations, we used the average annual price. We made no attempt to adjust the estimate for changes in technology - the implicit assumption is that the cost of water transfers and desalination and water recycling has remained constant over the time-period.

\section{Results}

Estimates of the volume of water in storage, inflows from precipitation and runoff, and reduction due to abstraction are summarized in Fig. 3. The water storage volume (GL) represents the average over the year for the combined ten Melbourne Water reservoirs. The total potential water storage of the ten reservoirs is $1812 \mathrm{GL}$ but the volume in storage, and hence the volume of the ecosystem service of water storage fluctuated by approximately $1000 \mathrm{GL}$ between around 600 and $1600 \mathrm{GL}$. The volume of inflow, representing the ecosystem service of 
Table 5

Accounting for ecosystem services related water supply in the Central Highlands of Victoria 2014-15: redefining production in the SNA.

\begin{tabular}{|c|c|c|c|c|c|c|c|c|c|c|c|}
\hline \multirow[t]{2}{*}{ PHYSICAL SUPPLY } & \multirow[b]{2}{*}{$\stackrel{\curvearrowleft}{\stackrel{\Xi}{\Sigma}}$} & \multicolumn{5}{|c|}{ Economic Unit } & \multicolumn{4}{|c|}{ Ecosystem Unit } & \multirow[b]{2}{*}{ 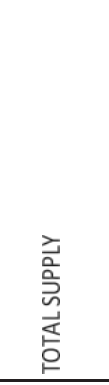 } \\
\hline & & 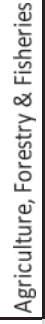 & 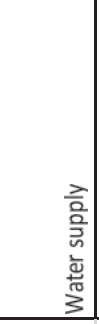 & 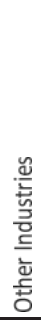 & 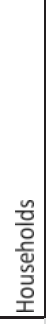 & 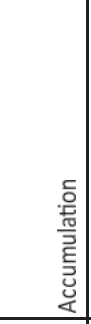 & 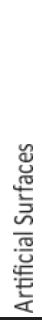 & 气 & $\begin{array}{l}\breve{\circlearrowleft} \\
\text { பு } \\
\end{array}$ & 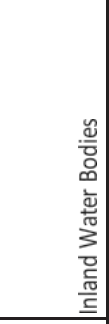 & \\
\hline \multicolumn{12}{|l|}{ Ecosystem Services } \\
\hline Water provisioning & $\mathrm{ML}$ & & & & & & & & 306,258 & & 306,258 \\
\hline Water filtration & $\mathrm{ML}^{*}$ & & & & & & & & 306,258 & & 306,258 \\
\hline Water storage & $\mathrm{ML}$ & & & & & & & & & $1,237,716$ & $1,237,716$ \\
\hline \multicolumn{12}{|l|}{ Products } \\
\hline Natural water (CPC 1800) & $\mathrm{ML}$ & & 306,258 & & & 95,591 & & & & & 401,849 \\
\hline
\end{tabular}

\begin{tabular}{|c|c|c|c|c|c|c|c|c|c|c|c|}
\hline \multirow[t]{2}{*}{ PHYSICAL USE } & \multirow[b]{2}{*}{$\stackrel{\curvearrowleft}{\stackrel{n}{\Sigma}}$} & \multicolumn{5}{|c|}{ Economic Unit } & \multicolumn{4}{|c|}{ Ecosystem Unit } & \multirow[b]{2}{*}{ 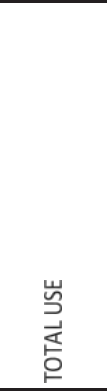 } \\
\hline & & 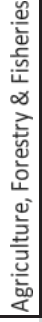 & 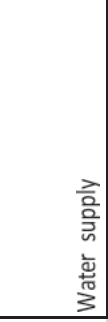 & 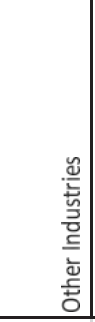 & 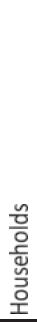 & 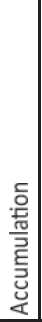 & 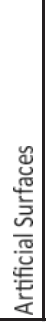 & 号 & $\begin{array}{l}\overleftarrow{\circlearrowleft} \\
\text { 혼 }\end{array}$ & 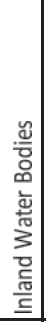 & \\
\hline \multicolumn{12}{|l|}{ Ecosystem Services } \\
\hline Water provisioning & ML & & 306,258 & & & & & & & & 306,258 \\
\hline Water filtration & $\mathrm{ML}^{*}$ & & 306,258 & & & & & & & & 306,258 \\
\hline Water storage & $\mathrm{ML}$ & & $1,237,716$ & & & & & & & & $1,237,716$ \\
\hline \multicolumn{12}{|c|}{\begin{tabular}{|l|l|} 
Products & \\
\end{tabular}} \\
\hline Natural water (CPC 1800) & $\mathrm{ML}$ & & & 401,849 & & & & & & & 401,849 \\
\hline
\end{tabular}

*Water filtration service would usually be measured as amount of sediment and other pollutants (e.g. pesticides, herbicides, $\mathrm{N}$, $\mathrm{P}, \mathrm{K}$, etc.) removed from the water. However, in this study this estimate was not made and instead the amount of water that was filtered is used as indicator to demonstrate how the tables would work.

water provisioning, also fluctuated, peaking in 1996 at just over 800 $\mathrm{GL} \mathrm{yr}^{-1}$ and lowest in 2006 at just under $200 \mathrm{GL} \mathrm{yr}^{-1}$. The pattern of inflow closely follows the pattern of rainfall. However, runoff is also influenced by season of rainfall and antecedent soil water content.

In Fig. 3, the water abstracted is the amount of water supply of "Natural Water" by Melbourne Water to its customers. The amount is not modelled but is the amount measured by Melbourne Water and reported in their Annual Reports. The pattern of water abstraction is reasonably constant around $400 \mathrm{GL} \mathrm{yr}^{-1}$. Supply and consumption of "Natural Water" are influenced by the region's population, which has been increasing over time (ABS, 2018), and efficiency of water use, which has been improving (ABS, 2017b). Overall, there is a trend of decreasing "Natural Water" consumption due to greater water use efficiency and investment in alternative water projects following the Millennium Drought (2001-2009), resulting in 23\% lower water use per person than pre-drought levels. However, water abstraction has increased slightly in the last four years, partly because of a growing population, although total levels of abstraction are still lower than predrought conditions (Melbourne Water, 2016). When volumes of inflows exceed abstractions (e.g. 2010 to 2012), this is reflected as an increase in water storage. The converse, when volumes of inflows are low, such as during drought, a key response is to impose water restrictions (e.g. no watering of house gardens) (Viggers et al., 2013), resulting in a decreasing rate of abstractions.

The amount of the water provisioning service from the catchments within the study area is shown by land cover type in Table 1 . The amount from each of the land cover classes depends on the area of land in each class, forest age, and precipitation and evaporation. Forests (open mixed, wet mixed, alpine ash (Eucalyptus delegatensis), mountain ash (Eucalyptus regnans) and cool temperate rainforest) provided most of the water provisioning service, accounting for around $85 \%$ of the total water provisioning service between 1990 and 2015. The forests also would be expected to provide a higher level of water filtration service than other land covers (e.g. pastures, crops, horticulture, builtup areas). Water quality was not considered in the accounts prepared but is important.

Summary data for Melbourne Water's water supply operations, including both monetary and physical measures are presented in Table 2. This shows standard metrics such as revenue, wages and operating expenses as well as the value of the ecosystem service of water provisioning used, and the amount in storage which could be taken as the volume of another ecosystem service, water storage. The total revenue received by Melbourne Water from water supply activities was AUD $\$ 876$ million in $2014-15$, up significantly from AUD\$144 million in 1999-2000. In 2014-15, the total industry value added (or contribution to GDP) from water supply was AUD\$318 million and the value of the ecosystem service of water provisioning was AUD\$75 million. The volume of water supplied has decreased between 2000 and 2015, while the revenue received has increased steeply since 2008 , with revenue increasing by $500 \%$ since $2007-08$.

The estimates of the total water provisioning services of water yield for the whole study area $(735,655$ ha) are shown in Table 1 . Only a part 
of these services are used by Melbourne Water as the water yield within the catchments for the reservoirs $(115,149 \mathrm{ha})$, and so the physical volumes of the water provisioning services shown in Tables 2 and 3 are less than for the total area.

The results from the two replacement cost options - transfer of water from other regions and desalination - for water provisioning are shown in Table 3. The least cost method is water transfer and hence this is the one presented in the summary. It is not known if the amount of water could be supplied by transfer from other regions (current infrastructure can transport $75 \mathrm{GL}$ per annum but it is presumed that this could be expanded). The replacement cost is likely to fall within the range of estimates from these two replacement options.

\section{Discussion}

\subsection{Accounting options}

Our study aligned the hydrological concepts of rainfall, runoff, and abstraction with SEEA-based accounting for ecosystem services and SNA accounting for products. Runoff into an artificial reservoir was deemed to be the ecosystem service of water provisioning, supplied by the forest ecosystem to the inland water body, which is managed by the water supply industry. To align with the current interpretation of the SNA production boundary, water provisioning is also shown as provided by the inland water body from which the water is abstracted by the water supply industry (Table 4). The total supply of the ecosystem service of water provisioning is $401,849 \mathrm{ML}$ and is from both the forest $(306,258 \mathrm{ML}$ the amount flowing into the inland water body) and the amount abstracted from the inland water body $(95,591 \mathrm{ML})$ by the water supply industry. The supply of ecosystem service of water provisioning is equal to the amount of the product "Natural Water" (CPC $1800)$ supplied by the water supply industry $(401,849 \mathrm{ML})$.

A second accounting option is to show the amount of water flowing into the water body $(306,258)$ as the only component of the water provisioning service (Table 5). The difference between the volume of "Natural Water" supplied and ecosystem service of water provisioning is the volume of water in storage and is accounted for as a supply from an inventory from within the economy. In this, if the volume of water "Natural Water" supplied was greater than the water provisioning service then the volume in storage would decrease. Conversely, if the volume of water "Natural Water" supplied was less than the water provisioning service then the volume in storage would increase. The effect over time would be seen in accounts of the different services and can be seen in Fig. 3, with inflows being the water provisioning service and the outflows being the supply of "Natural Water" along with the net change in water storage. This essentially redefines production of "Natural Water" (CPC 1800) from its current treatment in the SNA as occurring when water leaves the reservoir, to occurring when it enters the reservoir used by water suppliers. This is the treatment previously proposed by Nagy et al. (2012) and Obst (2012).

A third accounting option would be to show flows of ecosystem services between ecosystem units, as well as between ecosystem units and economic units. This is the treatment shown in Fig. $2 \mathrm{~b}$ and in this case of the Central Highlands, the flows between ecosystem units would be a supply of $306,258 \mathrm{ML}$ by forests to inland water bodies, while supply from ecosystem units to economic units would be 401,849 ML from inland water bodies to the water supply industry.

A key area for discussion (and agreement) is consistency in defining when ecosystem services are produced and used. In the case of water, which can be stored and there may be differences between when the service of water provisioning is used and when the product "Natural Water" (CPC 1800) is produced and used. Table 5 shows "Natural Water" (CPC 1800) to be produced when it enters the reservoir managed by a water supply industry. This treatment means that the water provisioning service from inland water bodies is not needed to reconcile the difference between "Natural Water" (CPC 1800) and the ecosystem service of water provisioning, as is shown in Table 4. While Table 5 is probably a neater accounting solution, it is not consistent with the current interpretation of the SNA production boundary, and the different stocks and flows of water are less transparent (as represented by Fig. 2c).

\subsection{Accounting for water filtration and water provisioning}

A question to answer for accounting is whether these water services are provided sequentially - that is the water filtration happens first and then water provisioning - or simultaneously. In this, the accounting reference period and the areas providing the services are important. If an annual accounting period is used, which is the case for virtually all business and government accounting, then it is reasonable to consider that they happen simultaneously, even if in the physical sense the water filtration service is provided ahead of the water provisioning service. In addition, if the area around the water source (e.g. the forested land) is considered with an artificial reservoir or other water source (e.g. lake) to be one ecosystem or spatial unit, then the two services would also be provided simultaneously and it may not be necessary to account for them separately for some purposes (e.g. valuation). This approach would seem appropriate for many water suppliers, since they are often responsible for both the management of the artificial reservoir (or other water source) as well as some of the land around the reservoir. This approach equates to that presented in Fig. $2 \mathrm{c}$ and Table 5.

\subsection{Valuing services}

Valuation using the least cost replacement method was possible in the Central Highlands of Victoria as real options for replacing the service were available and the estimates could be easily adjusted for changes in the physical amount of the service used, as well as inflation. The values from this study could not be used uncritically in other studies. Transferring the values from one study to another, known as "benefit transfer", is an area of on-going discussion in the development of the SEEA, and valuation of the environment and ecosystem services more generally (e.g. UN, 2017). While benefit transfer is an attractive proposition, the value of ecosystem services are usually strongly dependent on environmental, economic, social and legal context, making it difficult to assume that values of ecosystem services generated in one study can be applied to another area (UN, 2014b). However, by using meta-analysis of water pricing studies, benefit transfer is suggested as a useful approach for valuing ecosystems services at larger scales (Grizzetti et al., 2016).

The water filtration service was not valued separately from water provisioning in this study, although the forests of the study area are presumed to supply most of this service to Melbourne Water and result in high quality water. In the Australian Capital Territory, fires in 2003 resulted in loss of the litter layer and soil protection, thus greatly diminishing water quality (White et al., 2006). To improve water quality to the standards in the Australian Drinking Water Guidelines (and hence could be supplied to consumers), $\$ 55 \mathrm{~m}$ was spent on new water treatment facilities (ACTEW, 2005), with an additional, $\$ 4.5 \mathrm{~m}$ allocated to catchment remediation with spending spread over three years (ACTEW, 2004). The cost of the new and upgraded water treatment facilities would be part of the replacement cost of the water filtration service and would be indicative of the value of this service in other parts of Australia.

The case study in the Central Highlands of Victoria provides useful information for decision making on the water supply system and ecosystem services in the study region. In particular, the example showed that the forests of the Central Highlands provide a significant proportion of the water provisioning services to Melbourne Water. In turn, Melbourne Water provides the product "Natural Water' to water retailers and their customers, as well as employment and economic benefits, which in 2014-15 was 841 people employed and industry 
value-added value of $\$ 318$ million.

\subsection{Conclusion}

The SEEA-based accounting approach has provided a useful starting point for testing the integration of traditional national accounts with the supply and use of ecosystem services. In particular, accounting and valuing the ecosystem services used in the water supply industry is possible, as we have shown for the Central Highlands of Victoria. The approach employed is likely to be applicable to other areas, industries and ecosystem services. The study aligned accounting and hydrological concepts and highlighted differences between the timing of use of ecosystem services by the water supply industry and the supply of the product "Natural Water" (CPC 1800) by the water supply industry. We demonstrated two accounting options that could reconcile these differences.

There are likely to be equivalent differences in the provisioning and supply of other ecosystem services, related products, and the industries that use them. Additional work will be needed to: (1) more fully develop consistent accounting approaches for the supply and use of ecosystem services and the links to the supply and use of goods and services shown in the traditional national accounts, and (2) ensure that there is a systematic approach to accounting for ecosystem assets and ecosystem services. In this, it is likely that a range of accounts will be needed and that not all aspects of interest to particular stakeholders can be reconciled in a single account for ecosystem services.

\section{Acknowledgements}

This paper grew out of broader discussions of ecosystem accounting occurring at the 24th Meeting of the London Group on Environmental Accounting, held 1-4 October 2018, Dublin, Ireland. We thank the Alessandra La Notte, Ken Bagstad, Sjoerd Schenau, Rocky Harris, Steve May, Carl Obst, Francois Soulard and anonymous reviewers for their thoughtful comments on draft versions of this paper.

\section{References}

ABS (Australian Bureau of Statistics), 2016. Consumer Price Index Calculator available at http://www.abs.gov.au/websitedbs/d3310114.nsf/home/Consumer+Price+Index + Inflation+Calculator.

ABS (Australian Bureau of Statistics), 2017a. Australian System of National Accounts, 2015-16. ABS Cat. No. 5204.0.

ABS (Australian Bureau of Statistics), 2017b. Water Account, Australia. ABS Cat. No. 4610.0.

ABS (Australian Bureau of Statistics) 2018. Australian Demographic Statistics, Mar 2018“ 20 September 2018. Retrieved 13 October 2018. Estimated Resident Population 31 Mar 2018. http://www.abs.gov.au/AUSSTATS/abs@.nsf/Lookup/3101.0Main +Features1Mar\%202018.

ACTEW, 2004. Annual Report 2003-04. https://www.iconwater.com.au/media-centre/ reports-and-publications/annual-reports.aspx.

ACTEW, 2005. Annual Report 2004-05. https://www.iconwater.com.au/media-centre/ reports-and-publications/annual-reports.aspx.

Bagstad, K., Darius, J.S., Waage, S., Winthrop, R., 2013. A comparative assessment of decision-support tools for ecosystem services quantification and valuation. Ecosyst. Serv. 5, e27-e39.

Barbier, E.B., 2014. Account for depreciation of natural capital. Nature 515, 32-33.

Barton, D.N. 2017. Monetary valuation methods in urban ecosystem accounting-examples of their relevance for municipal policy and planning in the Oslo metropolitan area. London Group meeting, "Methodology of SEEA CF and the Ecosystem Accounts", 17-20 October 2017, Costa Rica. https://seea.un.org/sites/seea.un.org/ files/lg23 barton_et_al. 2017 _ urban_eea_-valuation_v3.pdf.

BoM (Bureau of Meteorology), 2016. National Water, Account. Canberra. http://www. bom.gov.au/water/nwa/2016/canberra/index.shtml.

Boyd, J., Banzhaf, S., 2007. What are ecosystem services? The need for standardized environmental accounting units. Ecol. Econ. 63 (2-3), 616-626. https://doi.org/10. 1016/j.ecolecon.2007.01.002.

Boyd, J.W., Bagstad, K.J., Ingram, J.C., Shapiro, C.D., Adkins, J.E., Casey, C.F., Duke, C.S., Glynn, P.D., Goldman, E., Grasso, M., Hass, J.I., Johnson, J.A., Lange, G.-M., Matuszak, J., Miller, A., Oleson, K.I.I., Posner, S.M., Rhodes, C., Soulard, F., Vardon, M., Villa, F., Voigt, B., Wentland, S. 2018. The natural capital accounting opportunity: let's really do the numbers. Bioscience 68(12): 940-943 (online 30 Oct 2018). https://doi.org/10.1093/biosci/biy135.

Clarke C., Lieu, D.K., Divisia, F., Perroux, F., Stone, J.R.N., Gilbert, M., 1949
Measurement of National Income: The Measurement of National Wealth: Discussion. Econometrica. 17: 255-272. DOI: 0012-9682(194907)17<255:TMONWD>2.0. CO;2-X.

Comisari, P., Feng, L., Freeman, B. 2011. Valuation of water resources and water infrastructure assets. Paper presented to the 17th London Group Meeting, Stockholm, Sweden. http://unstats.un.org/unsd/envaccounting/londongroup/meeting17/LG17 12.pdf.

Daily, G.C., 1999. Developing a Scientific Basis for Managing Earth's Life Support Systems. Ecology and Society 3(2): 14. [online] URL: http://www.consecol.org/vol3/ iss2/art14/ (accessed 3 Jan 2019).

Delgado, A., Rodriguez, D.J., Sohns, A.A. 2015. Thirsty Energy: Understanding the Linkages between Energy and Water. Live Wire, 2015/41. World Bank, Washington, DC. http://hdl.handle.net/10986/21576.

Department of Treasury and Finance. 2009. Partnerships Victoria Project Summary: Victorian Desalination Plant. http://www.dtf.vic.gov.au/files/283d4937-f253-4be7ae34-a1cb00ef0353/Project-Summary-for-Victorian- Desalination-Project.pdf.

DELWP (Department of the Environment, Land, Water and Planning). 2015. Victorian Water Trading 2013-14 Annual Report.

Dunne, T., Zhang, W., Aubry, B.F., 1991. Effects of rainfall, vegetation and microtopography on infiltration and runoff. Water Resour. Res. 27 (9), 2271-2285.

EC (European Commission), Food and Agriculture Organization, Organisation for Economic Co-operation and Development, United Nations, and World Bank. 2009. System of National Accounts 2008. New York: United Nations. https://unstats.un. org/unsd/nationalaccount/docs/SNA2008.pdf.

Edens, B., Graveland, C., 2014. Experimental valuation of Dutch water resources according to SNA and SEEA. Water Resour. Econ. 7 (2014), 66-81. https://doi.org/10. 1016/j.wre.2014.10.003.

Egoh, B., Drakou, E.G., Dunbar, M.B., Maes, J., and Willemen, L., 2012. Indicators for mapping ecosystem services: a review. Report EUR 25456 EN. Publications Office of the European Union, Luxembourg. https://www.researchgate.net/publication/ 233831375 Indicators for mapping ecosystem services a review.

Eigenraam, M., Obst, C., 2018. Extending the production boundary of the System of National Accounts (SNA) to classify and account for ecosystem services. Ecosyst. Health Sustainability. https://doi.org/10.1080/20964129.2018.1524718.

ESC (Essential Services Commission) 2016. Melbourne Water Price Review, Final Decision. https://www.esc.vic.gov.au/sites/default/files/documents/Water-PriceReview-2016-2021-Melbourne-Water-Final-Decision-1. pdf 9view 21 Jan 2019).

Fenichel, E.P., Abbott, J.K., Bayham, J., Boone, W., Haacker, E., Pfeiffer, M.K., 2016. Measuring the value of groundwater and other forms of natural capital. PNAS 113 (9), 2382-2387.

Finisdore, J., Rhodes, C., Haines-Young, R., Maynard, S., Wielgus, J., Dvarskas, A. Houdet, J., Quétier, F., Ding, H., Soulard, F., Van Houtven, G., Rowcroft, P., Lamothe, K., 2019. Expanding the field of ecosystem services practitioners -18 benefits from using classification systems (Version 1.1, March 2019). Available from: https://www. researchgate.net/publication/329402275_Expanding_the_field_of_ecosystem_services_practitioners-

Frame, J., Hand, J., Miles, N., Potter, M., Pettigrove, V., Lucas, A., Dabal, R., Crosbie, N. D., Yurisich, R., Tan, K.S., 2009 Melbourne Water's_recovery_response to the Black Saturday bushfires. Melbourne Water Corporation, Victoria.

Grizzetti, B., Lanzanova, D., Liquete, C., Reynaud, A., Cardoso, A.C., 2016. Assessing water ecosystem services for water resource management. Environ. Sci. Policy 61 194-203.

Hackbart, V.C.S., de Lima, G.T.N.P., dos Santos, R.F., 2017. Theory and practice of water ecosystem services valuation: where are we going? Ecosyst. Serv. 23, 218-227. https://doi.org/10.1016/j.ecoser.2016.12.010.

Keith, H., Vardon, M., Stein, J.A., Stein, L., Lindenmayer, D., 2017. Ecosystem accounts define explicit and spatial trade-offs for managing natural resources. Nature Ecol. Evol. https://doi.org/10.1038/s41559-017-0309-1. https://www.nature.com/ articles/s41559-017-0309-1.

Keynes, J.M., 1936. The General Theory of Employment, Interest, and Money. Macmillan, London. https://cas2.umkc.edu/economics/people/facultypages/kregel/courses/ econ645/winter2011/generaltheory.pdf [accessed 4 January 2019].

Kuznets, S., 1949. Measurement of National Income: national income and industrial structure. Econometrica 17, 205-241.

Landers, D.H., and Nahlik, A.M. 2013. Final Ecosystem Goods and Services Classification System (FEGS-CS). EPA/600/R-13/ORD-004914. U.S. Environmental Protection Agency, Office of Research and Development, Washington, D.C.

Langford, K.J., 1976. Change in yield of water following a bushfire in a forest of Eucalyptus regnans. J. Hydrol. 29, 87-114.

La Notte, A., Valleceillo, S., Marques, A., Maes, J., 2019. Beyond the economic boundaries to account for ecosystem services. Ecosyst. Serv. 35, 2016-2129. https://doi.org/10. 1016/j.ecoser.2018.12.007.

Martinez-Harms, M.J., Balvanera, P. 2012. Methods for mapping ecosystem service supply: a review. Int. J. Biodiversity Sci. Ecosyst. Serv. Manage. 8 (1-2), 17-25. https://doi.org/10.1080/21513732.2012.663792.

Melbourne Water, 2009. 2009 Water Plan. Melbourne Water, Melbourne.

Millennium Ecosystem Assessment, 2005. Ecosystems and Human Well-being: Synthesis. Island Press, Washington, DC.

Maes, J., Teller, A., Erhard, M. Liquete, C., Braat, L., Berry P., Bidoglio G., 2013. Mapping and Assessment of Ecosystems and their Services, An Analytical Framework for Ecosystem Assessments under Action 5 of the EU Biodiversity Strategy to 2020, Publications Office of the European Union, Luxembourg.

Melbourne Water. 2000 to 2015. Annual Reports. http://www.melbournewater.com.au/ aboutus/reportsandpublications/Annual-Report/Pages/Annual-Report-archive.aspx.

Melbourne Water. 2016. Water storage data. http://www.melbournewater.com.au/waterdata/waterstorages/pages/water-storages.aspx. 
Nagy, M., Alfieri, A., Vardon, M., 2012. Water in artificial reservoirs - a produced asset? Paper for the 14th Meeting of the London Group on Environmental Accounting Canberra, 27 - 30 April 2009. LG/14/13 https://unstats.un.org/unsd/envaccounting/londongroup/meeting14/LG14_13a.pdf.

Nordhaus, W.D., Tobin, J., 1972. Is growth obsolete? In Economic research: retrospect and prospect vol. 5: economic growth, ed. W. D. Nordhaus and J. Tobin, 1-80. Cambridge: National Bureau of Economic Research. http://www.nber.org/chapters/ c7620.

NRCCGER (National Resource Council Commission on Geosciences, Environment and Resources), 1999. Watershed Management for Potable Water Supply: Assessing the New YorkCity Strategy. Washington DC: National Academy Press.

Obst, C. 2012. Issue \#16: The treatment of water in artificial reservoirs. Outcome paper for Global Consultation. United Nations Statistics Division, New York. https://unstats.un.org/unsd/envaccounting/seearev/OCdocs/Outcome16.pdf.

Obst, C., Hein, L., Edens, B., 2015. National accounting and the valuation of ecosystem assets and their services. Environ. Resour. Econ. https://doi.org/10.1007/s10640015-9921-1.

Portela R., Bezerra M.O., Alam M., Shaad K., Banerjee O., Honzák M. 2019. Discussion paper 8: Water Supply Services: Biophysical Modeling and Economic Valuation in Ecosystem Accounting. Paper submitted to the Expert Meeting on Advancing the Measurement of Ecosystem Services for Ecosystem Accounting, New York, 22-24 January 2019 and subsequently revised. Version of 15 March 2019. Available at: https://seea.un.org/sites/seea.un.org/files/discussion_paper_8_-_water_supply_service_final.pdf.

Rockström, J., Steffen, W., Noone, K., Persson, Å., Chapin III, F.S., Lambin, E., Lenton, T.M., Scheffer, M., et al., 2009. Planetary boundaries: exploring the safe operating space for humanity. Ecol. Soc. 14 (2), 32. http://www.ecologyandsociety.org/vol14/ iss $2 /$ art32/.

Ruggles, N.D., Ruggles, R., 1999. National Accounting and Economic Policy: The United States and UN Systems. Edward Elgar, Northampton.

Ruijs, A., Vardon, M., Bass, S., Ahlroth, S., 2018. Natural capital accounting for better policy. Ambio: doi: 10.1007/s13280-018-1107-y.

Smith, B., Summers, D., Vardon, M., 2017. Environmental-economic accounts for ACT State of the Environment Reporting: Proof of concept, ACT Office of the Commissioner for Sustainability and the Environment, Canberra, Australia.

Stuvel, G., 1955. The use of national accounts in economic analysis. Rev. Income Wealth 4 (1), 262-321.

USEPA (United States Environmental Protection Agency). 2015. National Ecosystem
Services Classification System (NESCS): Framework Design and Policy Application. EPA-800-R-15-002. United States Environmental Protection Agency, Washington, DC

UN (United Nations), 1953. A System of National Accounts and Supporting Tables. ST/ STAT/Ser.F/No. 2. United Nations Department of Economic Affairs, Statistical Office, New York. https://unstats.un.org/unsd/nationalaccount/docs/1953SNA.pdf [accessed 29 Jan 2018].

UN (United Nations). 2015. Central Product Classification Version 2.1. United Nations, New York. https://unstats.un.org/unsd/classifications/unsdclassifications/cpcv21. pdf.

UN (United Nations), 2017. Technical Recommendations in support of the System of Environmental-Economic Accounting 2012- Experimental Ecosystem Accounting. New York, United Nations., https://seea.un.org/sites/seea.un.org/files/technical_recommendations_in_support_of_the_seea_eea_final_white_cover.pdf.

UN (United Nations), European Commission, Food and Agriculture Organization, International Monetary Fund, Organisation for Economic Co-operation and Development, World Bank. 2014a. System of Environmental-Economic Accounting 2012 - Central Framework. New York: United Nations.

UN (United Nations), European Commission, Food and Agriculture Organization, Organisation for Economic Co-operation and Development, World Bank. 2014b. System of Environmental-Economic Accounting 2012 - Experimental Ecosystem Accounting. New York: United Nations.

USEPA (United States Enviroment Protection Agency) Vardon, M., Martinez-Lagunes, R. Gan, H., and Nagy, M. (2012). The System of Environmental-Economic Accounting for Water: Development, Implementation and Use. In Godfrey, J. and Chalmers, K. (Eds) International Water Accounting: Effective Management of a Scarce Resource. Edward Elgar.

Vardon, M., Keith, H., Obst, C., Lindenmayer, D., 2018. Putting biodiversity into the national accounts: creating a new paradigm for economic decisions. Ambio. https:// doi.org/10.1007/s13280-018-1114-z.

Vertessy, R.A., Watson, F.G.R., O'Sullivan, S.K., 2001. Factors determining relations between stand age and catchment water balance in mountain ash forests. Forest Ecol. Manage. 143, 13-26.

Viggers, J., Weaver, H., Lindenmayer, D., 2013. Melbourne's Water Catchments: Perspectives on a World-Class Water Supply. CSIRO Publishing, Canberra.

White, I., Wade, A., Barnes, R., Mueller, N., Worthy M., Knee, R., 2006. Impacts of the January 2003. Wildfires on ACT Water Supply Catchments. 